\title{
Genetic mapping of the FACC gene and linkage analysis in Fanconi anaemia families
}

Division of Medical and Molecular Genetics, UMDS, Guy's Hospital, 8th Floor, Guy's Tower, London SE1 9RT, UK

R A Gibson

F Birjandi

M Murer-Orlando

C G Mathew

Section of

Epidemiology,

Institute of Cancer

Research, Surrey, UK

D Ford

D F Easton

Departments of

Human Genetics and

Paediatrics, University

of the Orange Free

State Medical School,

Bloemfontein, South

Africa

$S$ Jansen

C Havenga

$\mathrm{T}$ Pearson

Servizio di Genetica Medica, IRCCS

Ospedale CSS, San

Giovanni Rotondo,

Italy

A Savoia

King Faisal Specialist Hospital and Research Centre, Riyadh, Saudi Arabia

R D Milner

S S Hussein

Departments of Human Genetics and Paediatrics, South African Institute of Medical Research and the University of the Witwatersrand, South Africa

T J de Ravel

R J Cohn

Divison of

Haematology, St George's Hospital Medical School, London, UK

S E Ball

Department of Haematology, Royal Postgraduate Medical School, Hammersmith Hospital, London, UK I Roberts

Centro di Genetica Medica, IFF/Fiocruz, Rio de Janeiro, Brazil J C Llerena

Karolinska Institute, Centre for Biotechnology, Huddinge, Sweden I Vorechovsky

Correspondence to Dr Mathew.

Received 18 April 1994 Revised version accepted for publication 8 July 1994

Rachel A Gibson, Deborah Ford, Stander Jansen, Anna Savoia, Charmaine Havenga, R David Milner, Thomy J de Ravel, Richard J Cohn, Sarah E Ball, Irene Roberts, Juan C Llerena, Igor Vorechovsky, Thomas Pearson, Farkondeh Birjandi, Syad S Hussein, Manuela Murer-Orlando, Douglas F Easton, Christopher G Mathew

\section{Abstract}

Fanconi anaemia is an autosomal recessive disorder associated with increased chromosome breakage and progressive bone marrow failure. The gene for complementation group C (FACC) has been cloned and mapped to chromosome 9q22.3, but neither its genetic location nor the proportion of patients belonging to group $C$ is known. We have used a polymorphism within the FACC gene to localise it within a $5 \mathrm{cM}$ interval on chromosome $9 \mathrm{q}$, bounded by D9S196/ D9S197 and D9S176. The genes for Gorlin's syndrome and multiple self-healing squamous epitheliomata have also been mapped to this interval. Linkage analysis with the three highly informative microsatellite polymorphisms flanking FACC in 36 Fanconi anaemia families showed that only $8 \%$ of families were linked to this locus. This indicates that the genes for the other Fanconi anaemia complementation groups must map to one or more different chromosomal locations. The markers also allowed rapid exclusion of $56 \%$ of the families in our panel from complementation group $\mathrm{C}$, thus substantially reducing the number of patients who need to be screened for FACC mutations.

( $¥$ Med Genet 1994;31:868-871)

Fanconi anaemia (FA) is an autosomal recessive inherited disorder associated with progressive bone marrow failure, a variety of congenital abnormalities, and a high incidence of acute non-lymphocytic leukaemia. ${ }^{1}$ The disorder is genetically heterogeneous, since four complementation groups have been detected by cell fusion experiments. ${ }^{2}$ Cells from FA patients are highly sensitive to DNA cross linking agents such as mitomycin $\mathrm{C}$ (MMC) and diepoxybutane (DEB), which suggests that a failure of DNA repair might be the underlying defect. The gene for FA group A has been mapped provisionally to the long arm of chromosome $20,{ }^{3}$ under the assumption of genetic heterogeneity. The group C gene (FACC) has been cloned by functional complementation, ${ }^{4}$ and localised to chromosome $9 \mathrm{q} 22.3$ by in situ hybridisation. ${ }^{2}$ The genomic structure of the coding sequence of the FACC gene has been elucidated, ${ }^{5}$ and mutations within it have been detected in several FA patients. ${ }^{467}$ However, the gene has not been localised on the genetic map, and it is not yet clear what proportion of cases of FA are caused by mutations within it.

Recently, we described a frequent $E c o$ RI restriction fragment length polymorphism (RFLP) in the FACC gene. ${ }^{8}$ We have now typed this marker in the reference families of the Centre D'Etude Du Polymorphisme Humain $(\mathrm{CEPH})$ collaboration in order to place it on the genetic linkage map. We have been able to localise the FACC gene to a small interval flanked by three highly polymorphic microsatellite polymorphisms, and have analysed these markers in a panel of 36 FA families to establish what proportion of them are likely to be from complementation group $\mathrm{C}$.

\section{Materials and methods}

A total of 36 families with a clinical diagnosis of FA were referred to the Regional Genetics Centre at Guy's Hospital for analysis. A summary of the geographical or ethnic origin of the families and their structure is given in the table. The clinical diagnosis was confirmed in all families by cytogenetic demonstration of hypersensitivity to the DNA cross linking agents DEB or MMC or both, as described by Cohen et al. ${ }^{9}$ Families in whom the index case was not hypersensitive to these agents were excluded from the linkage study.

The EcoRI RFLP in the FACC gene was typed in the parents of the 40 families of the CEPH collaboration using the polymerase chain reaction ${ }^{10}$ with the primer sequences described. $^{8}$ The microsatellite polymorphisms D9S196, D9S197, and D9S176 ${ }^{11}$ were typed in some CEPH persons for whom no data on these markers were available. Typing was done by end labelling one of each of the PCR primers with $\gamma^{32} \mathrm{P}$-ATP, followed by PCR and analysis on denaturing polyacrylamide gels. ${ }^{12}$ D9S196 and D9S197 were amplified together in the same reaction tube with 22 PCR cycles at an annealing temperature of $65^{\circ} \mathrm{C}$, and D9S 176 was amplified separately for 23 cycles and annealing at $63^{\circ} \mathrm{C}$. All three markers can be analysed together on one lane of the gel as their allele sizes do not overlap (fig 1). Typing of persons in whom recombination was detected between closely linked markers was repeated to exclude laboratory error.

A linkage map of the region of interest on chromosome $9 q$ was constructed using CRI$\mathrm{MAP}^{13}$ and used to map the position of the FACC gene relative to other markers. The map 
Characteristics of the 36 FA families in the linkage panel

\begin{tabular}{lccc}
\hline Geographical/ethnic origin & $\begin{array}{l}\text { No of } \\
\text { families }\end{array}$ & $\begin{array}{l}\text { No of } \\
\text { sibs }\end{array}$ & $\begin{array}{l}\text { No of multiplex } \\
\text { families }^{*}\end{array}$ \\
\hline South African/Afrikaner & 13 & 34 & 3 \\
South African/Black & 2 & 6 & 2 \\
Middle East/Arabic & 5 & 25 & 4 \\
Brazil/Brazilian & 3 & 5 & 3 \\
East European & 3 & 5 & 2 \\
West European & 2 & 5 & 1 \\
UK/Asian & 4 & 10 & 3 \\
UK/White & 4 & 8 & 1 \\
Total & 36 & 98 & 19 \\
\hline
\end{tabular}

* Multiplex implies more than one affected person or that the parents are related to each other or both.
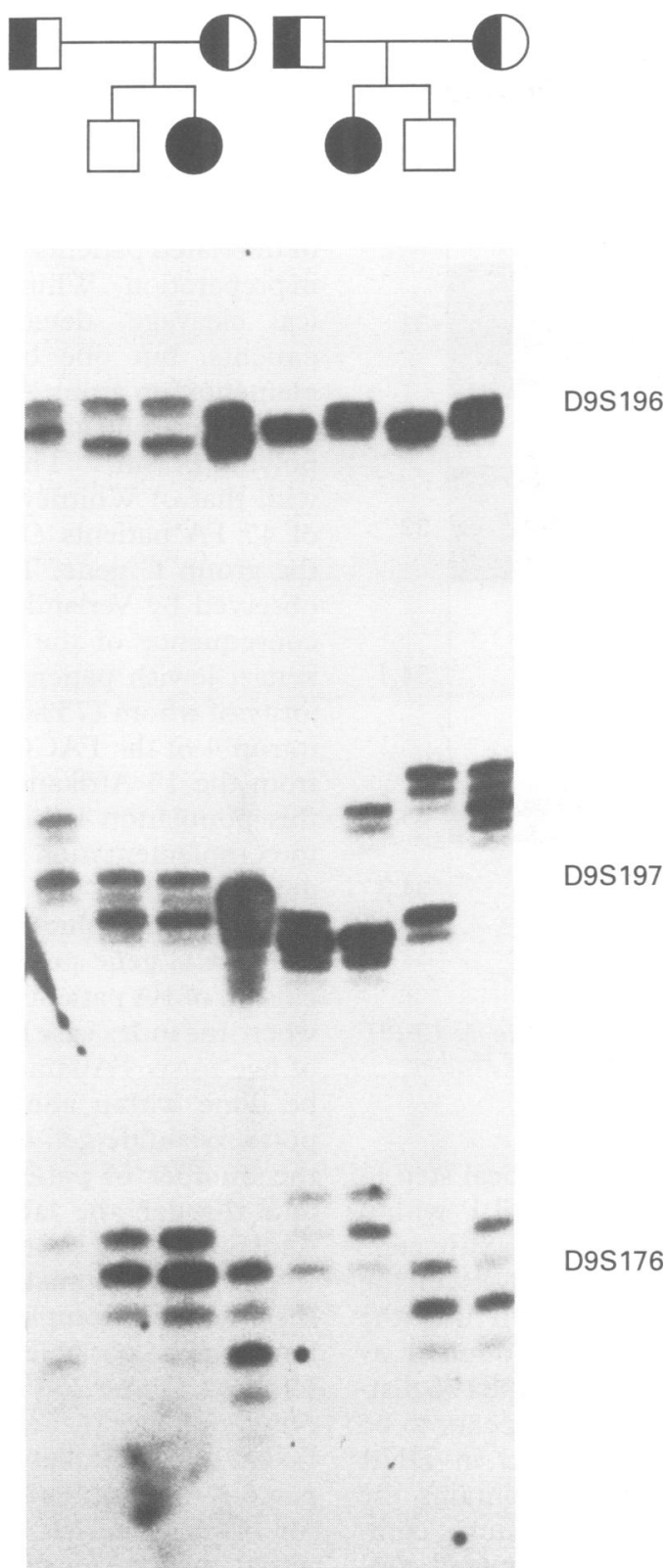

Figure 1 Linkage analysis of the FACC locus in Fanconi anaemia families. The FACC locus is not linked to the FA phenotype in the family on the left. In the family on the right, the genotypes are consistent with, but do not prove, linkage.

was based on the dataset constructed by the Cooperative Human Linkage Centre. ${ }^{14}$ The FACC RFLP and flanking markers from the Genethon group were then typed in our panel of 36 families with Fanconi anaemia. Multipoint lod scores for each family between the markers D9S196/D9S197 (considered as a haplotype), D9S176, and the disease were com- puted using LINKAGE, ${ }^{15}$ with the disease locus placed at the maximum likelihood position of FACC as determined by the CRIMAP analysis. The proportion of families linked to FACC was estimated using a standard admixture analysis. ${ }^{16}$ Genotypic data for the microsatellite markers in the 36 FA families are available on request.

\section{Results}

Analysis of the FACC RFLP in the CEPH families and the FA families showed that FACC was located between D9S20 and D9S176, an interval of $8 \mathrm{cM}$, with odds of more than $10^{6}$ over other positions. Its location in the $5 \mathrm{cM}$ interval between D9S196/D9S197 and D9S176 was supported with odds of $2506: 1$. A map of these and other markers in the region is shown in fig 2 . The availability of highly informative microsatellite markers which flank the FACC gene allowed us to address the question of what proportion of FA families might be linked to this locus.

Linkage between the FACC locus, as defined by the haplotype D9S196/D9S197-D9S176, and Fanconi anaemia was determined in the 36 families with a cytogenetically confirmed diagnosis of FA. There was no evidence for linkage overall, with a total lod score of $-38 \cdot 8$ at the FACC locus. Independent segregation of the FACC markers from the FA phenotype was observed in 20 of the 36 families in the panel, but some smaller families were consistent with linkage (see fig 1 for examples). A standard admixture test ${ }^{16}$ was used, under the assumption of genetic heterogeneity, to calculate the proportion of linked families. The best estimate was found to be $8 \%$, with $95 \%$ confidence limits of $0-35 \%$. Our linkage panel included 13 families from the Afrikaner population of South Africa, which has the highest reported incidence of FA (1 in 22 000) in the world. It has been suggested that this might result from a founder effect, ${ }^{17}$ in which case the population would be likely to be relatively homogeneous with respect to FA complementation group. The total lod score for linkage of the FACC locus to FA in this group of families was $-8 \cdot 4$. There were no families of Ashkenazi Jewish origin in our panel, a high proportion of whom are from group C. ${ }^{7}$

The three highly informative markers which flank FACC and which can be analysed together in the same lane of a sequencing gel provide a rapid screen for exclusion of FA families from complementation group C. In fig 1 , for example, the family on the left can be excluded from group $\mathrm{C}$ since the son, who is unaffected clinically and who does not show increased chromosome breakage, has inherited the same haplotype as his affected sister. The haplotypes in the family on the right are consistent with linkage to FACC, and cannot therefore be excluded from group $C$.

\section{Discussion}

A major goal of the Human Genome Project is to establish a physical map of all known genes and DNA segments. The creation of a 


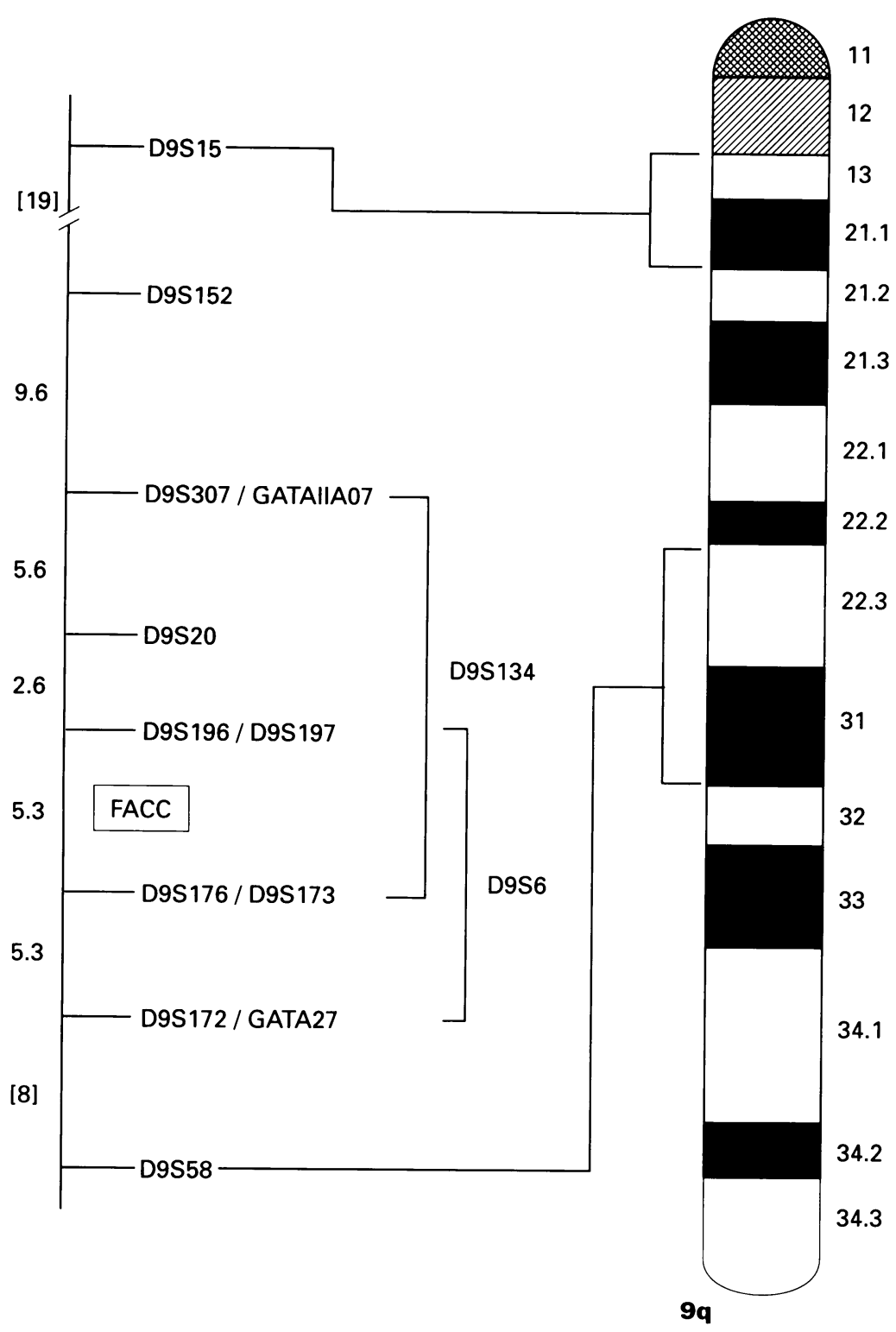

Figure 2 Linkage map of markers ordered with odds of greater than $10^{3}: 1$ in the CEPH families. Physical locations are taken from the Genome Database, The fohns Hopkins University. or ESS1 solely on phenotypic grounds.

Our analysis suggests that mutations in the FACC gene are responsible for the Fanconi anaemia phenotype in only a small minority of FA families, the best estimate being $8 \%$. Thus the genes which specify the other complementation groups must map to one or more other loci, and it is not necessary to invoke the hypothesis of intragenic complementation to explain the cellular heterogeneity in FA. This is in contrast to the situation in ataxia telangiectasia, where the genes in virtually all families and complementation groups map to the same locus on chromosome $11 \mathrm{q} 23 .{ }^{23}$ Our estimate of $8 \%$ agrees well with the results we have obtained from mutation analysis of the FACC gene in FA patients. We have screened the full FACC coding sequence by chemical cleavage, and detected mutations in $2 / 30(7 \%)$ of unrelated patients ${ }^{6}$ (Gibson et al, manuscript in preparation). Whitney et al, ${ }^{7}$ also using chemical cleavage, detected mutations in $4 / 17$ patients, but one of these was from complementation group $\mathrm{A}$, and the mutation in this patient was later shown to be a coding sequence polymorphism. ${ }^{24}$ Thus, combining our data with that of Whitney et $a l^{7}$ a total of five out of $47 \mathrm{FA}$ patients $(10.6 \%)$ had mutations in the group $\mathrm{C}$ gene. The higher figure of $14 \%$ observed by Verlander et $a^{l^{4}}$ is likely to be a consequence of the high proportion of Ashkenazi Jewish patients in their study, the majority of whom $(75 \%)$ had a splice mutation in intron 4 of the FACC gene. ${ }^{7}$ Our linkage data from the 13 Afrikaner families suggest that if this population is homogeneous with respect to complementation group, it will not be from group C.

The polymorphic markers within and around the FACC gene provide a rapid means of exclusion of FA patients from group $\mathrm{C}$ in families where the index case has at least one sib. Typing of five to six FA families with the markers can be done within about 24 hours on a single polyacrylamide gel, and has more than halved the number of patients that we have had to take through the labour intensive process of screening the 14 exons of FACC for mutations.

The chromosomal location of the genes for the other FA complementation groups is unknown. The possible linkage of the FA-A gene to chromosome $20 \mathrm{q}^{3}$ could be resolved by carrying out complementation analysis on sufficient FA families with multiple affected persons to assemble a panel of group A families for linkage analysis. This approach has been initiated by means of a European collaborative group (EUFAR) founded to promote research into Fanconi anaemia.

This work was supported by research grants from the British Medical Research Council, the Generation Trust, the South African Medical Research Council, the Italian Ministry of Health and Telethon-Italy (E.33), and FABUK. The statistical analysis was supported by the Cancer Research Campaign, and genotypic data on chromosome $9 \mathrm{q}$ markers was obtained from the CEPH collaboration. We are grateful to many clinica colleagues who referred FA patients to us, and to the FA families themselves, without whose cooperation this work would not have been possible.

1 Gordon-Smith EC, Rutherford TR. Fanconi anemia: constitutional aplastic anemia. Semin Hematol 1991;28:10412.

2 Strathdee CA, Duncan AMV, Buchwald M. Evidence for plasia type 2 and Hirschsprung's disease ${ }^{21}$ suggests that the FACC gene should not be excluded as a candidate for Gorlin's syndrome 
at least four Fanconi anaemia genes including FACC on chromosome 9. Nature Genet 1992;1:196-8.

3 Mann WR, Venkatrai VS, Allen RG, et al. Fanconi anaemia: evidence for linkage heterogeneity on chromosome $20 \mathrm{q}$.

4 Strathdee CA, Gavish H, Shannon WR, Buchwald M. Cloning of CDNAs for Fanconi's anaemia by functional complementation. Nature 1992;356:763-7.

5 Gibson RA, Buchwald M, Roberts RG, Mathew CG. Characterisation of the exon structure of the Fanconi anaemia group C gene by vectorette PCR. Hum Mol Genet 1993; 2:35-8.

6 Gibson RA, Hajianpour A, Murer-Orlando M, Buchwald $M$, Mathew CG. A nonsense mutation and exon skipping
in the Fanconi anaemia group C gene. Hum Mol Genet 1993;2:797-9.

7 Whitney MA, Saito H, Jakobs PM, Gibson RA, Moses RE, Grompe $M$. A common mutation in the FACC gene causes Fanconi anaemia in Ashkenazi Jews. Nature Genet 1993;4:202-5.

8 Gibson RA, Savoia A, Buchwald M, Mathew CG. EcoRI RFLP in the Fanconi anaemia complementation group C RFLP in the Fanconi anaemia complement

9 Cohen MM, Fruchtman CE, Simpson SJ, Martin A. The cytogenetic response of Fanconi's anemia lymphoblastoid cell lines to various clastogens. Cytogenet Cell Genet 1982; 34:230-40.

10 Saiki RK, Gelfand DH, Stoffel S, et al. Primer-directed enzymatic amplification of DNA with a thermostable DNA polymerase. Science 1988;239:487-91.

11 Weissenbach J, Gyapay G, Dib C, et al. A second-generation linkage map of the human genome. Nature 1992;359: 794-801.

12 Weber JL, May PE., Abundant class of human DNA polymorphisms which can be typed using the polymerase chain reaction. Am ₹ Hum Genet 1989;44:388-96.

13 Lander ES, Green P. Construction of multilocus genetic linkage maps in humans. Proc Natl Acad Sci USA 1987;
84:2363-7.

14 Buetow $\mathrm{KH}$, Weber JL, Ludwigsen S, et al. Integrated human genome-wide maps constructed using the CEPH reference panel. Nature Genet 1004;6:391-3.

15 Lathrop M, Lalouel JM, Julier C, Ott J. Multilocus linkage analysis in humans: detection of linkage and estimatio of recombination. Am f Hum Genet 1985;37:482-98.

16 Ott J. Analysis of human genetic linkage. Baltimore: Johns Hopkins University Press, 1985.

17 Rosendorff J, Bernstein R, MacDougall L, Jenkins T. Fanconi anemia: another disease of unusually high prevalence in the Afrikaans population of South Africa. $\mathrm{Am} \mathrm{f}$ Med Genet 1987;2:793-7.

18 Tanaka K, Miura N, Satokata I, et al. Analysis of a human DNA excision repair gene involved in group A xeroderma pigmentosum and containing a zinc-finger domain. Nature 1990;348:73-6.

19 Farndon PA, Del Mastro RG, Evans DG, Kilpatrick MW. Location of gene for Gorlin syndrome. Lancet 1992;339: 581-2.

20 Goudie DR, Yuille MA, Leversha MA. Multiple self-healing squamous epitheliomata (ESS1) mapped to chromosome squamous epitheliomata (ESS1) mapped to chromosome 9q22-q31 in famil

21 Romeo G, Ronchetto P, Luo Y, et al. Point mutations affecting the tyrosine kinase domain of the RET protooncogene in Hirschsprung's disease. Nature 1994;367: 377-8

22 Edery P, Lyonnet S, Mulligan LM, et al. Mutations of the RET proto-oncogene in Hirschsprung's disease. Nature 1994;356:378-80.

23 Foroud T, Wei S, Ziv Y, et al. Localization of an ataxiatelangiectasia locus to a 3-cM interval on chromosome 11q23: linkage analysis of 111 families by an international consortium. Am f Hum Genet 1991;49:1263-79.

24 Verlander PC, Lin JD, Udono MU, et al. Mutation analysis of the Fanconi anaemia gene FACC. Am f Hum Genet 1994;54:595-601. 